\title{
Empowering Theory of Poverty Reduction for Sustainable Development: Does the Welfare of Descendants Matter?
}

\section{Wspieranie teorii ograniczania ubóstwa dla zrównoważonego rozwoju: czy dobro przyszłych pokoleń ma znaczenie?}

\section{Juliusz Piwowarski ${ }^{\star}$, Larysa Yankovska**, Bohdan-Petro Koshovyi ${ }^{\star \star \star}$, Ira Von-Nagy ${ }^{\star \star \star \star}$, Andrii Yevstakhevych ${ }^{\star \star \star \star \star}$}

* University of Public and Individual Security "Apeiron" in Cracow, Krupnicza 3, 31-123 Kraków, Poland, E-mail: science2@apeiron.edu.pl, ORCID: 0000-0002-9196-1194

**Lviv University of Business and Law, Kulparkivska, 99, 79021 Lviv, Ukraine E-mail: larisalubp@gmail.com,ORCID:0000-0003-1855-0169

***Lviv University of Business and Law, Department of Demography,

Labor Relations and Social Policy, Kulparkivska str., 99, 79021 Lviv, Ukraine

E-mail (Corresponding Author): qqbkqq@gmail.com,ORCID:0000-0001-8550-0028.

****Fachärztin für HNO-Heilkunde, Chiemgauerstraße 144, 81549 München, Germany

E-mail: info@dr-ira-nagy.de, ORCID:0000-0002-2748-7766

*****Lviv University of Business and Law, Department of Business Economics and Information Technology, Kulparkivska, 99, 79021 Lviv, Ukraine

E-mail: yevstakhevych10@meta.ua,ORCID:0000-0003-1058-5359se

\begin{abstract}
The first Sustainable Development Goal expresses the global concern in poverty eradication. We looked at the theory of poverty reduction with a long-term perspective in mind to confirm the congruence of modern approaches and their compliance with the principles of sustainable development. Despite clear signs of targeting Sustainable development goals to the future, we have found that future poverty needs deep discussion. We researched legal acts, policies and scientific sources to prove the possibility and suitability of recognising future poverty as a valid form of poverty. We considered the main possible difficulties that will challenge initiatives of future poverty exhausting. Finally, we proposed several perspective directions of further research to include the future poverty concept into the agenda of governments and supranational organisations.
\end{abstract}

Keywords: future poverty, Sustainable development goals, forms of poverty, poverty reduction policy

\section{Streszczenie}

Pierwszy Cel Zrównoważonego Rozwoju wyraża globalną troskę o eliminację ubóstwa. W tej pracy przyjrzeliśmy się teorii ograniczania ubóstwa w perspektywie długoterminowej, aby potwierdzić zgodność nowoczesnych podejść i ich zgodność z zasadami zrównoważonego rozwoju. Pomimo wyraźnych oznak ukierunkowania Celów zrównoważonego rozwoju na przyszłość, stwierdziliśmy, że kwestia przyszłego ubóstwa wymaga dodatkowej uwagi. Przeanalizowaliśmy akty prawne, polityki i źródła naukowe, aby udowodnić możliwość i stosowność uznania przyszłego ubóstwa za ważną formę ubóstwa. Zastanowiliśmy się nad głównymi możliwymi trudnościami, które będą wyzwaniem dla przyszłych inicjatyw ograniczających ubóstwo. W końcu zaproponowaliśmy kilka perspektywicznych kierunków dalszych badan, aby włączyć koncepcję przyszłego ubóstwa do programu rządów i organizacji ponadnarodowych.

Słowa kluczowe: przyszłe ubóstwo, Cele zrównoważonego rozwoju, typy ubóstwa, polityka zmniejszania ubóstwa 


\section{Introduction}

Overcoming poverty is at the top of the list of sustainable development goals set out in Transforming our world: the 2030 Agenda for Sustainable Development. In addition, the UN General Assembly recognises that eradicating poverty in all its forms and dimensions, including extreme poverty, is the greatest global challenge and an indispensable requirement for sustainable development (General Assembly of the United Nations, 2015).

Public welfare is essential for the peace and prosperity of every state. In the long run, the wealth of the state will not matter if the people are unhappy. Cicero said: Salus popŭli - suprēma lex (The welfare of the people shall be the supreme law). Poverty has always existed in social systems (Atkins, 2006). Historically, poverty has been criticised and glorified (Jones, 2010). Before the rise of the social economy theory, poverty was usually an individual or family problem. Until the emergence of sustainable development theory, it remained a problem of region or state. Nowadays, due to the deepening globalisation processes, poverty has acquired the status of a global problem determining the direction of future development for the whole human civilisation.

The problem of poverty in the global dimension has remained relevant in recent decades. In 2019 A. Banerjee, E. Duflo and M. Kremer won The Nobel Prize in Economic Sciences for their experimental approach to alleviating global poverty (Nobel Foundation, 2019). However, the only theory of poverty is still far from complete.

The apparent reason for the absence of a general poverty reduction theory is states' individualism, differences in their political models and mechanisms, in the level of economic development, income, opportunities, and culture. The General Assembly recognises the freedom of each state to develop and implement its different instruments to overcome poverty (General Assembly of the United Nations, 2015). However, this freedom is a two-sided blade. On the one hand, states can respond flexibly to the needs of citizens and address economic insecurity. However, on the other hand, states can adopt declarative acts that speak loudly about poverty but do not contain tangible steps to overcome it.

Understanding poverty in the dimension of sustainable development requires two questions that we can ask any citizen worldwide: What is poverty?, Why the money is in the first place, after all?. Of course, the answer to the first question can include concepts like restriction, lack, unsatisfied needs, perhaps even situation. However, in modern society, access to goods is limited mainly by price, and the perception of poverty as a money deficiency has been ingrained in mass mindsets. The second question aims to clarify the differences in access to privileges separating the poor and other groups. These issues are central to sustainable poverty reduction policies. Unfortuna- tely, the data show that there is no straightforward solution at the global level.

According to The United Nations (UN) standards (PPP $\$ 1.90$ a day), in 2020 , from $0.8 \%$ to $45.7 \%$ of certain regions' populations were below the poverty line. The worst situation was in Sub-Saharan Africa $(43.4 \%$ and $45.7 \%)$ and South Asia $(22.9 \%$ and $18.2 \%$ ). The anti-leaders in the ranking (according to the UN standard) were Madagascar (77.6\%), Congo (76.6\%), Burundi (71.8\%), Malawi (70.3\%), Central African Republic (66.3\%), Mozambique (62.9\%).

However, some countries reported complete or almost complete eradication of critical poverty - Kyrgyzstan (0.9\%), Sri Lanka (0.8\%), Mongolia (0.5\%), and the Dominican Republic $(0.4 \%)$, Tunisia $(0.2 \%)$, Jordan $(0.1 \%)$, Kazakhstan $(0 \%)$, Maldives $(0 \%)$, Thailand (0\%), Ukraine (0\%) and others (UNDP, 2020). Maybe then our research does not meet the needs of time? Should governments simply use the experience of countries that have successfully overcome acute poverty? Unfortunately, this is a deadend.

Poverty has been, and probably will be, one of humanity's unresolved problems for decades to come. The UN successively includes poverty on the global agenda, but unfortunately, that is not enough. As Schleicher, J., Schaafsma, M., \& Vira, B. (2018) rightly point out, sustainable development goals are the basis for a holistic perception of poverty, but their weakness is differences in interpretation. From the standpoint of a sustainable approach, we can see a crucial weakness of current anti-poverty policies the almost complete absence of sight on the future. Nobel laureates Banerjee, A. V., \& Duflo, E. (2011) called for a rethinking of poverty in the spatial dimension. Today, the spatial dimension is a popular area of research on poverty and ways to overcome it (Fan, 2021). However, researchers and governments often unnoticed the temporal dimension of poverty, although UNDP (2020) emphasises the importance of eradicating poverty in all its forms and preserving the results achieved in a changing world.

In 2012, Ukraine reported almost complete eradication of poverty, $0 \%$ according to the UN standard and $1.3 \%$ according to the national standard. However, in 2019 State Statistical Service of Ukraine reported negative changes. Absolute poverty (according to the national standard, about $\$ 2.2$ a day) was $1.1 \%$, relative poverty (at a poverty line of about $\$$ 3.6 a day) was $24.4 \%$ (State Statistical Service of Ukraine, 2019). Thus, the pre-2012 policies were impactful for poverty reduction but did not affect results preservation.

Governments are glad to report on poverty alleviation, but they do not consider sustainability principles and do not care about results preservation in the long term due to different reasons.

We wish to advance views on poverty reduction as a long-term process, not a one-time activity or shortterm phenomenon. Long-term planning has limita- 
tions. The longer the term, the higher are the uncertainty and risks associated with predictive difficulties and changes in the influence of known or new factors. There are currently limited global plans to tackle poverty for more than a decade. The time frame of Global Sustainable Development Goals is about 15 years. However, the transition of persons to the status of adults occurs according to various criteria at 18, 21, and even 27 years. Should we take into account the change of generations that will occur during the implementation of a plan? Does a sustainable approach require assurances that our descendants will not live in poverty?

We rely on the idea of sustainable development and believe that the world should be better for posterity. We do not want to leave poverty to posterity, just as we do not want to leave hunger, global warming, and inequality to them. Thus, we will explore the theory of overcoming poverty from the standpoint of sustainable development, with a view to the distant future, when children born in the year of approval of the Sustainable Development Goals will become adults.

\section{Literature review: spatial and temporal ap- proaches to poverty}

The Sustainable Development Goals (SDGs) are global and address the universal problems of humanity. Schleicher, J., Schaafsma, M., \& Vira, B. (2018) pointed to the significant potential of SDG in solving complex problems related to development, society, and the environment. At the same time, Sopilnyk, R., \& Piwowarski, J. (2021) emphasised the dynamic nature of SDG, which germinating need for continuous enrichment of their content and interpretation.

Overcoming poverty in all its forms is the first of the SDGs. We explore the importance of sustainable development goals for the future and, therefore, we must note the lack of a time label in the formulation of the first goal. The first goal is mainly about the widespread eradication of poverty and let us call this approach spatial.

As we will see further, the spatial approach is now dominant in poverty studies. Current empirical research is mainly based on data provided by supranational institutions like the UN, the World Bank, et cetera, or by national statistical services. The data allows identifying the link between poverty reduction policies and changes in this area, clarifying the factors that affect the growth or reduction of the poor people share in the population. These data are the basis of short-term states strategies and also it is used to assess the success of reforms.

We understand the spatial approach as focused on overcoming poverty today (or in the imminent future), in isolation from the sustainable development principles. Considered space can be geographical, social or economic, real or virtual (for ex. data or draft space). However, this approach is strictly limited to the present and past. The primary tool of the spatial approach is retrospective and comparative analysis.

The spatial approach we observed, for example, in the article by Fan, S., \& Cho, E. E. (2021), who explored policies to stimulate farming, migration to cities, and the creation of social protection networks for rural residents. Alternatively, Alkire, S., Oldiges, C., \& Kanagaratnam, U. (2021) proposed a significant extension of the Multidimensional Poverty Index to assess the resilience of people falling out of poverty. Chen, S., \& Ravallion, M. (2007) described the development of approaches to poverty assessment during 1981-2004. They found that the approach to estimating household income remained dominant but had shortcomings. Thorbecke, E. (2013) made a relatively straightforward critique of income-based approaches to poverty assessment. Finally, Deaton, A. (2005) pointed to bottlenecks in the methodology for assessing the links between economic growth and poverty reduction.

The above and other studies are significant, as they form the basis for planning policies and measures to timely overcome poverty, especially critical. Nevertheless, something in human nature (or in the world economic model) does not allow us to overcome poverty in a short time and preserve results. Therefore, to find the answer to the problem of total poverty eradication, we should consider a spatial-temporal approach.

Going beyond the spatial approach means the transition to a Spatio-temporal coordinate system. The problem of poverty is much more profound if we look at it in the space-time dimension. Sutter, C., Bruton, G. D., \& Chen, J. (2019) partially covered this issue, emphasising the long-term nature of business reforms to reduce poverty. Ding, J., Wang, Z., Liu, Y., \& Yu, F. (2020) noted the importance of a long-term synergy effect in the people - industry land system for sustainable poverty alleviation.

Similar links between poverty and sustainable development, as described by Fan, S., \& Cho, EE (2021), were investigated by Tonn, B., Hawkins, B., Rose, E., \& Marincic, M. (2021). Their work shows a clear focus on the future. In particular, the researchers pointed to the expected increase in the number of poor and health problems in the United States. In addition, they described factors (such as climate change, ageing, housing, automation of production) that will remain relevant in the coming decades.

We can partially explain the need for approach change through the requirement of parallel implementation of the altruistic model that underlies the theory of sustainable development and the intergenerational sustainability dilemma. This problem extends to all areas of research and policy concerning the prospects of human civilisation. For example, in philosophical work on the Anthropocene, Bai, X. et 
al. (2016) state: Much of the debate about the Anthropocene has focused on interpreting past and present changes while saying little about the future.

However, sustainable development researchers are gradually strengthening and expanding their future vision. The transition from spatial to spatial-temporal perception of sustainable development is associated with changes in politics, society, and the psychology of people. The study results by Vainio, A., Pulkka, A., Paloniemi, R., Varho, V., \& Tapio, P. (2020) indicate the existence of a political need to include assessment of the near and distant future into socio-psychological models of people's sustainable behaviour.

Psychological aspects of sustainable development combine into the concept of intergenerational equity, which denotes care for future generations (Golub, 2013). Researchers of sustainable development are actively developing this concept and gathering convincing empirical evidence. For example, Pandit, A., Nakagawa, Y., Timilsina, RR, Kotani, K., \& Saijo, T. (2021) conducted a field experiment to study the sustainable management of solid waste and proved that the needs of imaginary future generations affect the population's perception of sustainability policy. Meanwhile, the results of an empirical study by Timilsina, R. R., Kotani, K., Nakagawa, Y., \& Saijo, T. (2021) indicate that the current generation acts primarily for their benefit and virtually ignores the interests of future generations. Researchers have pointed out that the urban population is less interested in sustainability. In contrast, the rural population have cohesion and the potential to solve the intergenerational equity problem. According to a study of an overlapping generations model, Dao, N. T., \& Edenhofer, O. (2018) proved that the economy could fall into the trap of poverty, fragile ecology and low life expectancy due to imperfect altruism between generations in a competitive economy.

How distant should the future be that we have to take it into account? Iwaniec, D. M. et al. (2020) investigated sustainable future scenarios in urban planning and identified three types, depending on the implementation period - short (up to five years), mediumterm (up to twenty years) and long-term (from forty to eighty years). Each type has its characteristics and benefits that are important for sustainable development. For example, Browning, M. H. E. M., \& Rigolon, A. (2019) found that the unexpected links between poverty, the environment, and politics can emerge in the long run.

The primary tool to look into the future from the standpoint of sustainable development is scenario modelling and planning. For example, Iwaniec, D. M. et al. (2020) proposed a system of Sustainable Future Scenarios to develop plausible, consistent representations of the future. Their work shows the time-spatial approach in the recommendations for improving scenario planning, decision-making, and building research capacity for long-term sustainability planning.

We do not consider it possible and appropriate to abandon the spatial approach because it would mean a departure from a sustainability paradigm in favour of abstract futurology.

Using the spatial-time approach, we should note the role of state and civil institutions. Koskimaa, V., Rapeli, L., \& Hiedanpää, J. (2021) pointed out that international commitments, semi-autonomous governance, and stakeholder participation are factors in the effectiveness of a sustainability policy with a view to the future. Similarly, Golub, A., Mahoney, M., \& Harlow, J. (2013) noted the importance of restorative justice to address sustainability issues in the light of intergenerational equity. Researchers have shown that restorative justice promotes social cohesion and improved resource management. To solve the problem of intergenerational equity, Dao, N. T., \& Edenhofer, O. (2018) noted the importance of ensuring a sustainable state of the social planner.

Regarding the spatial-time approach, poverty reduction policies must back up the future vision for sustainable development. For example, Edward, P., \& Sumner, A. (2014) noted significant differences in the methods and outcomes of assessing global poverty's future extent and spread. Thus, researchers have proposed a specific model for obtaining a consistent set of long-term global poverty estimates. On the other hand, Iwaniec, D., Childers, D., VanLehn, K., \& Wiek, A. (2014) insisted on the expediency of visionary modelling, which means the development of viable and sustainable visions in compliance with the principles of sustainability and differs from normative scenario planning. This method combines temporal (visions of desired states) and spatial (modelling based on governments, experts and stakeholders participation) elements.

After all, current research relies on policymakers' demand, which rarely goes beyond retrospective analysis and short-term forecasts. Therefore, based on a literature review, we formulated the following research questions:

$\mathrm{RQ}_{1}$ : Is the modern concept of poverty sufficiently future-oriented?

$\mathrm{RQ}_{2}$ : Is it possible to identify a future-oriented form of poverty?

$\mathrm{RQ}_{3}$ : What problems arise if we consider the policy of overcoming poverty with a view to the future?

Addressing these issues will strengthen the theory of overcoming poverty and focus its development on the long term.

\section{Results}

\section{1. Is the current concept of poverty future-ori-} ented?

We begin our research by analysing the meaning and content of the poverty concept. The first goal of sus- 
tainable development points to poverty and all its forms that we must overcome together. However, the very definition of poverty is debatable.

Many factors influence the classification of a person as poor, and it is challenging to unify them at the global level. Therefore, governments do not pay attention to the definition of poverty because it can complicate the policy of its reduction. The anti-poverty policies and reforms based on the poverty threshold concept confirm the above assumption.

Despite criticism regarding the unsuitability for long-term planning (Edward, 2014), the poverty threshold is quite common at the global and national levels because of its clarity and simplicity. There are two groups of people - poor and not needy, divided here and now by income. Everyone can compare their income with the poverty threshold standard and find out about their belonging to the poor. Each government can assess the number of poor citizens. Simplicity lies in the method of evaluation and availability of data and the ways of governmental response. Supposing poverty is related to income makes the slight raising of minimal wages an obvious answer. On this background, the idea of overcoming poverty in all its forms breaks, and descendants receive future poverty provoked by ineffective short-term policies.

Despite the apparent limitations, the idea and instrument of the poverty threshold play an integral role in stimulating government action to contend poverty. For example, the US Global Poverty Act of 2007 defines extreme global poverty and the US role in its eradication. In addition, the US Recognizing Poverty Act provides the basics of reforms to overcome poverty by shifting the poverty line. A similar trend is present in European legislation.

In Article 208 of the Treaty on the Functioning of the European Union (2016), the key objective of the Union development cooperation policy is to reduce and, finally, eradicate poverty. Accordingly, the European Commission (2010) included the poverty threshold concept in the Europe 2020 strategy. However, specifying the targets for 2020, the European Commission drew attention to the interrelation between the movement of European citizens above the poverty line, employment, education, science and the environment.

The expanded interpretation of poverty as a phenomenon that concerns more than just income is the multidimensional approach. This approach became widespread in the late 1990s. In 2001, the United Nations Committee on Economic, Social and Cultural Rights (UN Committee) stressed the gradual abandonment of past views on poverty as a lack of income. Instead, the UN Committee proposed that poverty be considered a lack of essential opportunities to meet people's needs, including food, education, dignity, social protection and inclusion.
In The Poverty Reduction Strategy for Asia and the Pacific, the Asian Development Bank (ADB) (1999) defined poverty as a condition in which a person is deprived of the primary means and opportunities to which he or she is entitled. ADB relates the state of poverty to the violation of human rights to work and remuneration, to be protected from external shocks, to participate in decision-making.

Transforming the concept of poverty to cover human rights is an essential step towards sustainable development. However, such a transformation must be careful because it can provoke a methodological shift. The interdisciplinary basis of the theory of sustainable development determines the probability of methodological pluralism. Studying poverty from the standpoint of human rights limits the coverage of the economic basis of related processes and vice versa - economic research is impossible without transforming abstract rights into specific economic concepts.

Haughton, J. H., \& Khandker, S. R. (2009) work is an excellent example to support our reasoning. They interpreted poverty as deprivation in well-being, which aligns with human rights violations. Scientists then considered two approaches to assessing such deprivation, its sources and characteristics: a) limitations in income and consumption and b) limitations in opportunities associated with the functioning of the entire society. UNDP also argues that poverty means not just making ends meet or paying the bills for basic services on time but is multidimensional (United Nations Development Program, 2018). We saw the development of this thesis in the UNDP report (2020), where the goal of calculating the Multidimensional Poverty Index sounds as to shift our attention from traditional income-based poverty measures towards a more holistic view of lived poverty.

Modern approaches to the interpretation of poverty have their supporters and opponents, are evolving and overgrown with new details, but, unfortunately, do not contain a time perspective. We can imagine extrapolating the approaches described above to the future, but in this case, they will contain too many unpredictable variables. The income of future generations depends not only on poverty reduction policies but also on many economic, social and behavioural factors. Similarly, the elimination of future restrictions on rights and opportunities must consider the future development of public relations and equality policies.

Unfortunately, we must recognise that the modern concept of poverty, which has recently undergone a multidimensional transformation, is still not sufficiently future-oriented. Thus, the injection of time perspective into the concept of overcoming poverty must be gradual. Nevertheless, the time perspective needs to acquire some form at the present stage, which has led us to the following question: is it possible that future poverty is a form of poverty? 


\subsection{Forms of poverty and future poverty}

A valid question about poverty, its forms and approaches to assessment was voiced by Pritchett, L. (2006): When the World Bank dreams of 'a world free of poverty', what should it be dreaming? Fighting abstract poverty is like fighting the world's oceans. Concretising efforts to overcome poverty requires a clear goal - a flow that can be blocked or diverted. Forms of poverty are becoming such a flow in relevant policies.

Generally, poverty is a complicated phenomenon to assess. Nevertheless, the concretisation of its forms allows governments to develop and justify sufficiently clear plans to overcome. Absolute and relative poverty are the primary forms government and supranational organisations operating with. Such a classification is the most universal and, at the same time, quite abstract.

The Council of Europe (2021) defines absolute poverty as the lack of sufficient resources to meet vital needs. It is this idea that underlies the poverty line. This form of poverty has a monetary expression enshrined in global documents. Globally, the Agenda for Sustainable Development contains the criterion of extreme poverty - to live on less than $\$ 1.25$ a day. In 2015, this criterion increased to $\$ 1.90$ (United Nations Development Program, 2018).

In 2018, the World Bank raised its absolute poverty lines, which are more flexible. Their values were $\$ 3.20$ in lower-middle-income countries and \$5.50 a day in upper-middle-income countries. In addition, the World Bank followed global trends and implemented the Multidimensional poverty measure. This tool aims to assess consumption, education, access to water, sanitation and electricity (World Bank, 2020-a). Delimitation of the object of assessment according to the criterion of absolute poverty lines is the first step to abandon this concept. Just as the World Bank calculates absolute poverty lines for lower-middle-income and upper-middle-income countries, we may require a separate calculation for agricultural or technological countries or countries with older populations. Ultimately, the differentiation of the evaluation base leads to the transformation of the absolute approach into a relative one. The Council of Europe (2021) points out that in Europe, poverty is usually understood as relative poverty, the availability of lower resources and opportunities for households than are considered adequate in a particular society.

It may be convenient for individual states to formulate a national strategy for overcoming poverty based on the poverty threshold concept (International Monetary Fund, 2016). However, the most clumsy method is artificially raising incomes (for example, by raising the minimum wage) without considering inflation. As a result, real incomes will remain the same, and may even decline, while the state will report a reduction in absolute poverty. Building a strategy to combat relative poverty can also suffer from manipulation. In 2013, the United Nations Economic and Social Commission for Asia and the Pacific found that economic growth in the region led to higher incomes for the poor, but the rich became even more wealthy. Income inequality has exacerbated the problems of the poor in various dimensions (United Nations Economic and Social Commission for Asia and the Pacific, 2013).

Thus, the notion of globalised relative poverty enters the arena, and we can treat it as the third known form of poverty - multidimensional poverty. The Council of Europe (2021) sees a new stage in developing approaches to poverty reduction in the emergence of the Human Development Index and other tools for assessing multidimensional poverty. In Banerjee, A. V., \& Duflo, E. (2011), multidimensional poverty is a holistic model based on the systemic theory of poverty. Liu, Y., \& Xu, Y. (2016) noted the importance of a multidimensional approach to developing poverty-based poverty reduction programs.

The needs and deprivations of the poor are fundamental concepts of the multidimensional approach (UNDP, 2020). The link between poverty and need is illustrated to some extent by the archetype of $\mathrm{Di}$ ogenes, who refused the cup when he saw a child drinking from the palms (Kardas, E. P., 2010). However, not everyone shares Diogenes' views.

There is an infinite number of combinations and variations of needs, and there are many approaches to their classification. Despite some difficulties in data collection, it is relatively easy to assess and compare people's needs. Everyone already needs food, shelter, security, and communication (Maslow, A. H., 1943). If we supplement this list with education, medicine, and transport infrastructure, we will have a ready framework for a multidimensional approach. Maybe it is worth focusing on three forms? Nevertheless, there is still no answer about integrating future poverty into the poverty reduction policy system.

The problem of the multidimensional approach is the disproportionate needs of individuals in the global, which creates requirements for simplification of the method of their evaluation and comparison, as written by Lanjouw, J., \& Lanjouw, P. (2001) and Ravallion, M. (1996). Also, what about forecasting the needs of future generations? This question is a little bit philosophical. Twenty years ago, it was difficult to predict that one of the most critical needs for posterity today would be access to the Internet or the availability of the COVID-19 vaccine. Today, the lack of Internet access and vaccines is an indicator of poverty.

The multidimensional approach complicates the formation of public policy. Under this approach, states have to provide a certain income level and ensure that the formally non-poor have all they need. This issue connects with income and non-income inequality, as the United Nations Economic and Social Commission found analysing the Millennium Devel- 
opment Goals implementation (Asia-Pacific aspirations: Perspectives for a post-2015 development agenda, 2013).

Finally, why should governments take poverty into account in the long run? The simple answer is because they are obliged by law. Such an obligation brings us to the fourth form of poverty, which we will call the poverty-in-rights. We will look at this form under an interdisciplinary approach, considering law, economics, and cultural aspects. The beauty of law is its stability allowing researchers to predict the future better than using mathematical instruments. However, we should take into account the role of economics and cultural factors in legal doctrine evolution.

In 2001, the United Nations Committee on Economic, Social, and Cultural Rights declared a human rights approach to poverty, designed to increase the effectiveness of poverty reduction policies. The Office of the United Nations High Commissioner for Human Rights (2004) noted that non-fulfilment of any human rights is a fairly complete and straightforward definition of poverty. This approach developed in parallel with the multidimensional and has similar features. Like the multidimensional, a human rights approach promotes a much broader interpretation of poverty than lack of income.

The second article of the Universal Declaration of Human Rights states that everyone has fundamental rights regardless of property status (United Nations, 1948). The Islamic Development Bank links poverty overcoming to the right of all people to live in dignity and prosperity (IsDB GROUP, 2021).

The UN Global Compact links poverty to a lack of freedom of speech and choice, access to social protection, the power to negotiate, decent work, and points to it as the root cause of many human and labour rights violations (UN Global Compact, n.d.). The United Nations Development Program (2018) also points to a clear link between poverty and human rights abuses.

The Office of the United Nations High Commissioner for Human Rights (2004) argued in favour of a human rights approach, arguing that any poverty reduction policy is basing on the norms and values established by international human rights law. However, a human rights approach has obvious limitations associated with law enforcement. Sometimes, there is an impregnable wall between the enshrined right and the opportunities for the poor to exercise it. This statement applies primarily to countries with a low level of economic development and/or a high level of corruption, where the state budget cannot cover all the items of expenditure necessary to ensure human rights. As a result, poor people forcedly suffer from poor nutrition and drug shortages, receive education in unfavourable conditions (Khilukha et al., 2020), and, finally, accept lower-paid work, which closes the circle of poverty for these people and their descendants. Nevertheless, even countries with the most robust economies have the same problems. For example, the Federal Safety Net (founded by Robert S. Pfeiffer) says that while federal programs have helped improve the lives of millions of Americans, many people are left behind because of poor education, disability, mental illness, or addiction to alcohol or drugs (Federal Safety Net, n.d.).

Thus, overcoming the poverty-in-rights form can have good results, but it is also difficult for states and governments. Is the concept of this form of poverty future-oriented? With some limitations, definitely yes. Establishing the rule of law and the dictates of human rights in the state will mean preserving these rights for posterity. The reliability of this method is commensurate with its complexity and can be challenged only as a result of the revolution, war, or global crisis.

The most important feature of the human rights approach is its potential in overcoming intergenerational conflict and achieving sustainability in this way. Uniform rules of the game, equality, and justice for all, guarantees from the state and international organisations - this is what we can achieve by using the human rights approach to poverty alleviation. Moreover, as Golub, A., Mahoney, M., \& Harlow, J. (2013) pointed out, a strong sense of justice between generations is the mainstay of sustainability.

Thus, we explored four forms of poverty (absolute, relative, multidimensional, and poverty-in-rights) that can be addressed through anti-poverty policies. Due to different countries' economic and cultural factors, some forms are wider described in policies, and others have only cognitive value. However, all discussed forms have one thing in common - they are an abstraction. As follows from the first SDG, poverty must be exterminated in all its forms. The conditional forms of poverty we have been talking about serving as guidelines for governments and supranational associations. Future poverty can be a similar higher-order abstraction with the same significance for sustainable development.

In order to adhere to the principle of Entia non sunt multiplicanda (Entities should not be multiplied unnecessarily), we can point to the mandatory nature of future poverty as property or component of each form of poverty or its consequence. We may require governments to include a calculation of the future effect of poverty alleviation measures in short-term policies or insist on in-depth calculations of the impact of education reforms on the educational deprivation of the poor in twenty years. But let us be honest, it will not change anything. We have already said that the needs of future generations are a mystery to us behind seven locks. Changing the culture and worldview of people can shake even the legal basis for overcoming poverty, the breakdown of which we have seen in the example of market transformations in post-socialist countries after the fall of the Soviet Union (Yankovska, 2021). Therefore, from the 
standpoint of sustainable development theory, we do not consider future poverty a tail of modern forms of poverty.

One way or another, any honest policy of overcoming poverty impacts all forms of poverty, including future poverty. Policies to increase the minimum income help to reduce inequality (relative poverty), increase the ability to receive education and maintain health (multidimensional poverty), enable living in dignity (poverty-in-rights), and, finally, create the conditions for prosperity in the future. Reducing relative poverty means balancing the minimum income at the higher level, equal access to quality health and education services, justice, and better prospects for descendants. Efforts to overcome multidimensional poverty give impetus to higher incomes, the inclusion of the poor, and the actual realisation of human rights. Reducing poverty-in-rights means that today and in the future, every right will be protected by state and society, including the right to decent work and earnings, welfare, education, health and personal development, and more.

If there is such a connection, why do poverty reduction policies ignore the poverty of future generations (Lavallée, 2010)? After all, in order for our descendants to live in prosperity, decisive action by governments is needed today to raise the population above the poverty line, ensure equality and access to social services, ensure the rule of law, and equal access to legal services. Let us find the guilty one.

\subsection{Future poverty and comfort of governments}

Poverty reduction targeting and timing have a solid link to governance and policies (Wang, 2020; Nguyen, 2021). Cobbinah, P. B., Erdiaw-Kwasie, M. O., \& Amoateng, P. (2015) emphasised the crucial role of governments in tackling poverty for sustainable development. Haughton, J. H., \& Khandker, S. R. (2009) noted that keeping poverty on the agenda is one of the crucial reasons measuring poverty is essential.

We do not have data on future poverty, so we must look for an alternative tool to stimulate progress in this direction. Moreover, we must never forget that a simplified interpretation of poverty is beneficial for political purposes. This view corresponds to the thesis of Koskimaa, V., Rapeli, L., \& Hiedanpää, J. (2021) regarding democracies that have difficulty in solving long-term problems. In addition, weak institutions generate reproduction patterns that lead to poverty (Ramos-Mejía, 2018).

Comfort of governments means a policy that can show good results in the short term. Short-term policies aimed at immediate positive results create a warm bath for the population - an imaginary feeling of positive change in the state. In turn, politicians receive widespread support. However, worrying about future poverty means breaking out of the comfort zone for politicians and the government. Schleicher, J., Schaafsma, M., \& Vira, B. (2018) pointed out that a broad interpretation of sustainable development goals can risk picking cherries - neglecting some of the challenging goals.

For sustainable development, governments must define poverty as broadly as possible. Instead, the lack of a single theory of poverty allows governments to pursue one of two types of policy: against poverty as a lack of money and against poverty as a lack of opportunity. Unfortunately, rare politicians will take on the burden and responsibility of the third type against poverty as a threat to future generations.

It is challenging to expect promotions of the third type of policy in countries experiencing economic problems. The source of such doubts is the eternal confrontation between short-term political interests and the long-term development strategy of the state. Fair and regular elections are a fundamental principle of democracy. However, the short tenure of most public positions raises politicians' desire to promise a lot but to fulfil only the simplest promises. The regression of the political system or national economic model (for example, the transition from democracy to tyranny or from capitalism to autocratic socialism) does not help because it exacerbates poverty-inrights.

Let us consider some of the challenges of including future poverty on the agenda related to governments' desire for political comfort.

1. Instability of sustainable policy. Fritzen, S. (2002) noted that the previous poverty alleviation policies in Vietnam were not focused on achieving equal growth in the long term. Thus, the sustainability of Vietnam's achievements in poverty reduction was not guaranteed. Sustainable development policies can wear a mask, but not be such. It is not necessary to make policy truly sustainable to achieve specific policy goals and create the appearance of reforms. Unstable sustainable development policies are unsuitable for overcoming future poverty, involves insignificant measures, and cannot be adequately integrated into the country's economic, social and cultural space. Moreover, such policies may distort or conceal current poverty data and ignore glaring cases of acute poverty.

2. Governments may accidentally or intentionally exclude key elements from policies to address future poverty. Deng, Q., Li, E., \& Zhang, P. (2020) developed the concept of forces to overcome poverty, followed by starting force, driving force and support force, (the basis of existence, acceleration and environment respectively) which must be balanced and supportive of each other; otherwise, sustainable development is impossible. Similarly, the exclusion from politics of one of the crucial elements of poverty alleviation will save budget funds but not endorse sustainability.

3. Funding to address future poverty does not yield immediate results. Abstractly, after helping sev- 
eral families below the poverty line, the government can report on poverty reduction based on concrete data. The clear consiquences of the fight against future poverty may become available in decades. Thus, the current government should reconcile that benefits from progress in overcoming future poverty will get future governments.

4. Corruption, embezzlement, and waste are harbingers of the demise of any best poverty reduction policy. Before undertaking future poverty, governments need to ensure that policy effectiveness is not affected by shadow factors. Otherwise, any measures to overcome future poverty can become a source of corruption.

5. Overcoming the 'selfishness of generations' requires governments to be highly professional, flexible, and active in organising and financing events and changing the culture and outlook of the population for sustainable development. In addition, according to Iwaniec, D., Childers, D., VanLehn, K., \& Wiek, A. (2014), governments need to become visionaries for overcoming future poverty, which will put forward transformational goals and a clear focus on the desirable future state.

Thus, to empower the theory of poverty reduction for sustainable development, we propose considering future poverty as one of the forms of poverty mentioned in the first SDG. Such a simple step, we believe, will help consolidate the efforts of poverty theorists and practitioners to strengthen relevant policies. According to Bai, X. et al. (2016), the scientific community needs to negotiate interdisciplinary questioning and joint resolution with stakeholders. We believe that the broader discussion of future poverty will inspire governments and, finally, improve the lives of our descendants, which is the main idea of sustainable development.

As our research is theoretical, we do not undertake to formulate recommendations for governments, but we can suggest further directions for research.

Joint efforts can lay the foundations for overcoming the poverty of future generations and harmonise the approaches of different governments, supranational entities, and institutions:

- lawyers could examine whether it is time to include the right not to be poor in their countries' constitutional rights,

- behaviourists should try to describe the behaviour of future generations and what we can do now to ensure that our descendants do not inherit patterns of poverty.

- economists can suggest ways to create opportunities for future generations by implementing long-term and long-term development projects, such as creating an international fund to combat future poverty.
- political, sociological and cultural researchers can seek new ways of promoting equality and social justice between generations.

\section{Limitation}

This study is theoretical and philosophical. We relied on the previous researches, legal acts, our own experience and observations to describe the desired interpretation of the first goal of sustainable development with a view to the future. Therefore, before implementing the above recommendations, they should be tested using empirical methods.

\section{Conclusions}

This study found that future poverty needs to be more widely represented in policies and discussed in the scientific community. We have proven the possibility and expediency of interpreting future poverty as a form of poverty like an absolute, relative, multidimensional and poverty-in-rights, which must be annihilated to achieve the first SDG. We also briefly noted the challenges governments and peoples might face in developing and implementing policies to address future poverty. As a result, we have outlined the critical directions for further research, strengthening policies to contend poverty with a view to the future.

This study is partly idealistic. We understand that the lack of food, clothing and shelter for modern people means much more than the illusory happiness of descendants. Nevertheless, we believe that the golden grain of sustainable development is growing in such a contradiction. By ignoring the poverty of future generations, society and governments doing the same as previous generations, which conducted nuclear tests, saturated the atmosphere with carbon, and polluted the oceans. It did not look like a problem in the past; technological progress was considered a boon for posterity. Now we have the consequences - global warming, chronic diseases, and extinction. Therefore, we should not hope that the descendants will cope with poverty on their own. We believe that governments and international organisations should look at the first SDG through this approach.

\section{References}

1. ALKIRE S., OLDIGES C., KANAGARATNAM U., 2021, Examining multidimensional poverty reduction in India 2005/6-2015/16: Insights and oversights of the headcount ratio, World Development, 142: 105454, DOI: 10.1016/j.worlddev.2021.105454.

2. Asian Development Bank, 1999, Fighting Poverty in Asia and the Pacific: The Poverty Reduction Strategy, https://think-asia.org/bitstream/handle/11540/48 76/Fighting\%20poverty\%20in\%20Asia\%20\%26\%2 0the $\% 20$ Pacific $\% 20-\% 20$ The $\% 20$ poverty $\% 20$ reduction $\% 20$ strategy $\% 20$ Nov99.pdf?sequence $=1$ (25.08.2021). 
3. ATKINS M., OSBORNE R., (eds.), 2006, Poverty in the Roman World, Cambridge University Press, DOI: $10.1017 / \mathrm{CBO} 9780511482700$.

4. BAI X., VAN DER LEEUW S., O'BRIEN K., BERKHOUT F., BIERMANN F., BRONDIZIO E. S., CUDENNEC C., DEARING J., DURAIAPPAH A., GLASER M., REVKIN A., STEFFEN W., SYVITSKI J., 2016, Plausible and desirable futures in the Anthropocene: A new research agenda, Global Environmental Change, 39: 351-362,

DOI: 10.1016/j.gloenvcha.2015.09.017.

5. BANERJEE A. V., DUFLO E., 2011, Poor economics: A radical rethinking of the way to fight global poverty, Public Affairs, https://search.ebscohost.com $/ \operatorname{login}$. aspx ?direct $=$ true $\&$ scope $=$ site $\& \mathrm{db}=$ nlebk $\& \mathrm{db}=$ nlabk\&AN=591663 (25.08.2021).

6. BRANDER P., 2021, COMPASS: A manual on human rights education with young people, https:// rm.coe.int/compass-eng-rev-2020-web/1680a08e40, (25.08.2021).

7. BROWNING M. H. E. M., RIGOLON A., 2019, Could nature help children rise out of poverty? Green space and future earnings from a cohort in ten U.S. cities, Environmental Research, 176: 108449,

DOI: 10.1016/j.envres.2019.04.016.

8. CHEN S., RAVALLION M., 2007, Poverty and Hunger Special Feature: Absolute poverty measures for the developing world, 1981-2004, Proceedings of the National Academy of Sciences, 104(43): 1675716762, DOI: 10.1073/pnas.0702930104.

9. COBBINAH P. B., ERDIAW-KWASIE M. O., AMOATENG P., 2015, Rethinking sustainable development within the framework of poverty and urbanisation in developing countries, Environmental Development, 13: 18-32,

DOI: 10.1016/j.envdev.2014.11.001.

10. DAO N. T., EDENHOFER O., 2018, On the fiscal strategies of escaping poverty-environment traps towards sustainable growth, Journal of Macroeconomics, 55: 253-273,

DOI: $10.1016 /$ j.jmacro.2017.10.007.

11. DEATON A., 2005, Measuring Poverty in a Growing World (or Measuring Growth in a Poor World), Review of Economics and Statistics, 87(1): 1-19,

DOI: 10.1162/0034653053327612.

12. DENG Q., LI E., ZHANG P., 2020, Livelihood sustainability and dynamic mechanisms of rural households out of poverty: An empirical analysis of Hua County, Henan Province, China, Habitat International, 99: 102160, DOI: $10.1016 /$ j.habitatint.2020.102160.

13. DESMOND W. D., 2006, The Greek Praise of Poverty: The Origins of Ancient Cynicism, University of Notre Dame Press.

14. DING J., WANG Z., LIU Y., YU F., 2020, Rural households' livelihood responses to industry-based poverty alleviation as a sustainable route out of poverty, Regional Sustainability, 1(1): 68-81,

DOI: 10.1016/j.regsus.2020.07.002

15. EDWARD P., SUMNER A., 2014, Estimating the Scale and Geography of Global Poverty Now and in the Future: How Much Difference Do Method and Assumptions Make? World Development, 58: 67-82, DOI: 10.1016/j.worlddev.2013.12.009.

16. EUROPEAN COMMISSION, 2010, Europe 2020: a strategy for smart, sustainable and inclusive growth,
http://eur-lex.europa.eu/LexUriServ/LexUriServ.do? uri=COM:2010:2020:FIN:EN:PDF, (25.08.2021).

17. FAN S., CHO E. E., 2021, Paths out of poverty: International experience, Journal of Integrative Agriculture, 20(4): 857-867, DOI: 10.1016/S2095-3119(20)63295-6.

18. FEDERAL SAFETY NET, n.d., U.S. Poverty Level or U.S. Poverty Rate, http://federalsafetynet.com/ uspoverty-level.html, (25.08.2021).

19. FRITZEN S., 2002, Growth, inequality and the future of poverty reduction in Vietnam, Journal of Asian Economics, 13(5): 635-657, DOI: 10.1016/S1049-0078(02)00173-2, (25.08.2021).

20. GENERAL ASSEMBLY OF THE UNITED NATIONS, 2015, Transforming our world: The 2030 Agenda for Sustainable Development, http://www.un.org/ga/search/view_doc.asp?symbol= $\mathrm{A} / \mathrm{RES} / 70 / 1 \&$ Lang=E (25.08.2021).

21. GOLUB A., MAHONEY M., HARLOW J., 2013, Sustainability and intergenerational equity: Do past injustices matter? Sustainability Science, 8(2): 269277, DOI: 10.1007/s11625-013-0201-0;

22. H.R. $5069\left(116^{\text {th }}\right)$ : The Recognizing Poverty Act, https://www.govtrack.us/congress/bills/116/hr5069, (25.08.2021).

23. HAUGHTON J. H., KHANDKER S. R., 2009, Handbook on poverty and inequality, https://openknow ledge.worldbank.org/bitstream/handle/10986/11985/ 9780821376133.pdf? sequence $=1 \&$ isallowed $=y$, (25.08.2021).

24. International Monetary Fund, 2016, Poverty Reduction Strategy Papers, https://www.imf.org/external/ np/prsp/prsp.aspx, (25.08.2021).

25. IsDB Group, (2021), IsDB Group in brief 1975 2021 (Q1): Empowering People for a Sustainable Future, https://www.isdb.org/sites/default/files/media/ documents/2021-05/IsDBG_Brief_2021_Q1\%20310 52021.pdf (25.08.2021).

26. IWANIEC D. M., COOK E. M., DAVIDSON M. J., BERBÉS-BLÁZQUEZ M., GEORGESCU M., KRAYENHOFF E. S., MIDDEL A., SAMPSON D. A., GRIMM N. B., 2020, The co-production of sustainable future scenarios, Landscape and Urban Planning, 197: 103744, DOI: 10.1016/j.landurbplan.2020.103744.

27. IWANIEC D., CHILDERS D., VANLEHN K., WIEK A., 2014, Studying, Teaching and Applying Sustainability Visions Using Systems Modeling, Sustainability, 6(7): 4452-4469, DOI: $10.3390 /$ su6074452.

28. JONES W., 2010, Philosophers and the Poor, Theoria: A Journal of Social and Political Theory, 57(125): 99-123, http://www.jstor.org/stable/418024 88, (25.08.2021).

29. KARDAS E. P., 2010, Diogenes of Sinope (412-323 BCE). History of psychology: The making of a science, http://peace.saumag.edu/faculty/kardas/courses /HP/Lectures/diogenes.html, (25.08.2021).

30. KENNEDY A., BOUDALAOUI-BURESI Z., 2021, The fight against poverty, social exclusion and discrimination, Fact Sheets on the European Union2021, https://www.europarl.europa.eu/ftu/pdf/en/FT U_2.3.9.pdf (25.08.2021).

31. KHILUKHA O., LIPYCH L., KUSHNIR M., FATENOK-TKACHUK A., 2020, Marketing Technologies 
in Higher Education for Identifying the Needs of Consumers in Lifelong Learning, International Journal of Higher Education, 9(6): 298-306,

DOI: $10.5430 /$ ijhe.v9n6p298.

32. KOSKIMAA V., RAPELI L., HIEDANPÄÄ J., 2021, Governing through strategies: How does Finland sustain a future-oriented environmental policy for the long term? Futures, 125: 102667, DOI: 10.1016/j.futures.2020.102667.

33. LANJOUW J. O., LANJOUW P., 2001, How to Compare Apples And Oranges: Poverty Measurement Based on Different Definitions of Consumption, Review of Income and Wealth, 47(1): 25-42, DOI: $10.1111 / 1475-4991.00002$.

34. LAVALLÉE E., OLIVIER A., PASQUIER-DOUMER L., ROBILLIARD A.-S., 2010, Poverty alleviation policy targeting: a review of experiences in developing countries, https://www.researchgate.net/ publication/46165291_Poverty_alleviation_policy_ targeting_a_review_of_experiences_in_developing _countries, (25.08.2021).

35. LIU Y., \& XU Y., 2016, A geographic identification of multidimensional poverty in rural China under the framework of sustainable livelihoods analysis, $A p$ plied Geography, 73: 62-76, DOI: 10.1016/j.apgeog.2016.06.004.

36. MAIRECH H., LÓPEZ-BERNAL Á., MORIONDO M., DIBARI C., REGNI L., PROIETTI P., VILLALOBOS F. J., TESTI L., 2021, Sustainability of olive growing in the Mediterranean area under future climate scenarios: Exploring the effects of intensification and deficit irrigation, European Journal of Agronomy, 129: 126319,

DOI: 10.1016/j.eja.2021.126319.

37. MARTINEZ F., PEATTIE K., VAZQUEZ-BRUST D., 2021, Faith in the future: On a mission to integrate sustainability into management theory and practice, Futures, 125: 102654, DOI: 10.1016/j.futu res.2020.102654.

38. MASLOW A. H., 1943, A theory of human motivation, Psychological Review, 50(4): 370-396, DOI: $10.1037 / \mathrm{h} 0054346$.

39. NGUYEN T. V., LV J. H., NGO V. Q., 2021, Factors determining upland farmers' participation in non-timber forest product value chains for sustainable poverty reduction in Vietnam, Forest Policy and Economics, 126: 102424,

DOI: 10.1016/j.forpol.2021.102424.

40. Nobel Foundation, 2019, Press release: The Prize in Economic Sciences 2019, https://www.nobelprize. org/prizes/economic-sciences/2019/press-release/, (25.08.2021).

41. Office of the United Nations High Commissioner for Human Rights, 2004, Human Rights and Poverty Reduction: A Conceptual Framework, https://www. ohchr.org/Documents/Publications/PovertyReductio nen.pdf, (25.08.2021).

42. PANDIT A., NAKAGAWA Y., TIMILSINA R. R., KOTANI K., SAIJO T., 2021, Taking the perspectives of future generations as an effective method for achieving sustainable waste management, Sustainable Production and Consumption, 27: 1526-1536. DOI: 10.1016/j.spc.2021.03.019.

43. PRITCHETT L., 2006, Who is Not Poor? Dreaming of a World Truly Free of Poverty, The World Bank Research Observer, 21(1): 1-23, DOI: $10.1093 /$ wbro/lkj002.
44. RAMOS-MEJÍA M., FRANCO-GARCIA M.-L., JAUREGUI-BECKER J. M., 2018, Sustainability transitions in the developing world: Challenges of socio-technical transformations unfolding in contexts of poverty, Environmental Science \& Policy, 84: 217 223, DOI: 10.1016/j.envsci.2017.03.010.

45. RAVALLION M., 1996, Issues in Measuring and Modelling Poverty, The Economic Journal, 106(438): 1328, DOI: 10.2307/2235525.

46. ROSER M., ORTIZ-OSPINA E., 2013, Global Extreme Poverty, OurWorldInData.org, https://ourwor ld indata.org/extreme-poverty, (25.08.2021).

47. S.2433 - Global Poverty Act of 2007, https://www. congress.gov/bill/110th-congress/senate-bill/2433/ text, (25.08.2021).

48. SAPENA J., ALMENAR V., APETREI A., ESCRIVÁ M., GIL M., 2018, Some reflections on poverty eradication, true development and sustainability within CST, Journal of Innovation \& Knowledge, 3(2): 90-92, DOI: $10.1016 /$ j.jik.2017.12.005.

49. SCHLEICHER, J., SCHAAFSMA M., VIRA B., 2018, Will the Sustainable Development Goals address the links between poverty and the natural environment? Current Opinion in Environmental Sustainability, 34: 43-47, DOI: $10.1016 /$ j.cosust.2018.09.004

50. SEN A., 2001, Development as freedom, Oxford University Press, http://fs2.american.edu/dfagel/www/ Philosophers/Sen/DevelopmentAsFreedomIntroNch 1NEW.pdf, (25.08.2021).

51. SOPILNYK R., PIWOWARSKI J., 2021, Access to a genuinely independent and impartial trial: a review of the sixteenth sustainability goal completeness, Law, Business and Sustainability Herald, 1(1): 43-53, DOI: $10.46489 / \mathrm{lbsh} .2021-1-1-5$.

52. STATE STATISTICAL SERVICE OF UKRAINE, 2019, Sotsialno-ekonomichne stanovyshche domohospodarstv Ukrainy u 2019 rotsi (za danymy vybirkovoho obstezhennia umov zhyttia domohospodarstv), http://www.ukrstat.gov.ua/operativ/operativ 2018/gdvdg/soc_ek_stan_dom_2019.zip, (25.08.2021).

53. SUTTER C., BRUTON G. D., CHEN J., 2019, Entrepreneurship as a solution to extreme poverty: A review and future research directions, Journal of Business Venturing, 34(1): 197-214, DOI: 10.1016/j.jbusvent.2018.06.003.

54. THORBECKE E., 2013, Multidimensional Poverty: Conceptual and Measurement Issues, The Many Dimensions of Poverty, Palgrave Macmillan UK, DOI: 10.1057/9780230592407_1.

55. TIMILSINA R. R., KOTANI K., NAKAGAWA Y., SAIJO T., 2021, Concerns for future generations in societies: A deliberative analysis of the intergenerational sustainability dilemma, Journal of Behavioral and Experimental Economics, 90: 101628, DOI: 10.1016/j.socec.2020.101628.

56. TONN B., HAWKINS B., ROSE E., MARINCIC M., 2021, A futures perspective of health, climate change and poverty in the United States, Futures, 131: 102759, DOI: 10.1016/j.futures.2021.102759.

57. UN Global Compact, n.d., Poverty, https://www.unglobalcompact.org/what-is-gc/our-work/social/poverty, (25.08.2021).

58. UNITED NATIONS COMMITTEE ON ECONOMIC, SOCIAL AND CULTURAL RIGHTS, 
2001, Substantive issues arising in the implementation of the international covenant on economic, social and cultural rights: poverty and the international covenant on economic, social and cultural rights, https://www2.ohchr.org/english/bodies/cescr/docs/ statements/E.C.12.2001.10Poverty-2001.pdf, (25.08.2021).

59. UNITED NATIONS DEVELOPMENT PROGRAMME, 2018, Beyond income: A broader picture of poverty, https://feature.undp.org/multidimensional 1-poverty/, (25.08.2021).

60. UNITED NATIONS DEVELOPMENT PROGRAMME, 2020, The next frontier human development and the Anthropocene, http://hdr.undp.org/sites/ files/hdr2020.pdf, (25.08.2021).

61. UNITED NATIONS ECONOMIC AND SOCIAL COMMISSION FOR ASIA AND THE PACIFIC, 2013, Asia-Pacific aspirations: Perspectives for a post-2015 development agenda, https://www.adb. org/sites/default/files/publication/30414/asia-pacificregional-mdgs-report.pdf, (25.08.2021).

62. UNITED NATIONS, 1948, Universal Declaration of Human Rights, https://www.un.org/sites/un2.un.org/ files/udhr.pdf, (25.08.2021).
63. VAINIO A., PULKKA A., PALONIEMI R., VARHO V., TAPIO P., 2020, Citizens' sustainable, future-oriented energy behaviours in energy transition, Journal of Cleaner Production, 245: 118801, DOI: $10.1016 /$ j.jclepro.2019.118801.

64. WANG Z., HUANG F., LIU J., SHUAI J., SHUAI C., 2020, Does solar PV bring a sustainable future to the poor? An empirical study of anti-poverty policy effects on environmental sustainability in rural China, Energy Policy, 145: 111723, DOI: 10.1016/j.enpol.2020.111723.

65. WONG H., 2015, Chinese definition of poverty, The SAGE encyclopedia of poverty, p. 232-233, https:// web.swk.cuhk.edu.hk/ hwong/pubfile/book/2015 Chinese_Definition_of_Poverty.pdf, (25.08.2021).

66. World Bank, 2020a, Poverty and Shared Prosperity 2020: Reversals of fortune, https://openknowledge. worldbank.org/bitstream/handle/10986/34496/97814 64816024.pdf, (25.08.2021)

67. YANKOVSKA L., Management of socio-economic systems in Ukraine: European integration paradigm, Global Prosperity, 1(1): 31-36, DOI: 10.46489/gpj.2021-1-1-3. 